\title{
ETHNIC ASSIMILATION AND ETHNODEMOGRAPHIC CHANGES IN SOUTH-EASTERN LITHUANIA IN THE LATE TWENTIETH CENTURY
}

\section{PETRAS KALNIUS \\ Lithuanian Institute of History, Vilnius}

This study deals with the south-eastern region of Lithuania, which borders with Belorussia. Ethnically it is the most heterogeneous part of the country, comprising the districts of Šalčininkai, Svenčionys, Trakai and Vilnius with their own administrative authorities. According to the 1989 census, the population of these districts (with the exception of the city of Vilnius) was 254,714 , equalling 6.9 per cent of the Republic's total population. ${ }^{1}$ The ethnic composition of the area was as follows: Poles made up 48.3 per cent, Lithuanians 34.8 per cent, Russians 10.5 per cent, Belorussians 4.5, and other ethnic groups (mostly Ukrainians, Tartars, Jews, Gypsies and Karaites) 2.1 per cent of the inhabitants. ${ }^{2}$ The south-eastern region of Lithuania is the least urbanized, heavily afforested area with many lakes and rivers. Its rural inhabitants make up 64 per cent of the local population (the average of the country is 32 per cent). ${ }^{3}$

During the period of the Grand Duchy of Lithuania before 1795 (excepting the temporary occupations in the wars of the seventeenth and sixteenth centuries) this region belonged to Lithuania, i.e., it constituted an integral part of the ethnic Lithuanian lands. Between the late eighteenth century and 1990 this area changed hands many times (eight times in the twentieth century alone). Nevertheless, even in this century these ethnic Lithuanian lands were in the jurisdiction of Lithuania in 1918, 1920 and 1939, though for very short periods of time). For some time (between the late 1920 and 1939) it was occupied by Poland, and in the last 200 years it was mostly ruled by tsarist Russia and the Soviet Union.

\footnotetext{
${ }^{1}$ Lietuvos gyventojai. Statistikos rinkinys. Vilnius, 1990, 18-19.

${ }^{2}$ Ibid.

${ }^{3}$ Lietuvos Respublikos pagrindiniu tautybiu gyventojai. Vilnius, 1991, 43-47.
} 
Ethnodemographic changes in any particular country are conditioned by population migrations, variations in the natural growth (births and deaths), and finally by the factors of forcible and natural assimilation of the inhabitants. The differences in the effectiveness of each of these factors in the formation of a particular ethnodemographic structure depend on various circumstances. The geographical situation of this south-eastern region constantly shaped the nature of its ethnic processes. The peculiarity of assimilation as one of its principal ethnic processes depended on the subordination of the area to a particular state. Between the late eighteenth and the last decade of the twentieth century the most conspicuous expression of assimilation was the forcible Russification or Polonization of the local population depending on the eventual jurisdictional subordination of the region and on the aims of the ruling circles with regard to ethnodemographic issues. These ethnic processes, among them natural assimilation in the first place, varied under the influence of subjective factors, as well.

The assimilation of this region has been analyzed in the work of Lithuanian ethnolinguists and in ethno-political and purely sociological studies of south-eastern Lithuania, and all of them stress the fact that this assimilation was the result of the activity of the former occupational regimes, of the chauvinistic organizations of the ruling nations and of a part of the Polish clergy, which was nationalistically minded. Institutional engagement meant the appearance of ethnic segments, such as state, national community, individual (as a member of that community). However, between the national community and the individual there is one more segment - a family, and that is a very important intermediary component. Additionally, in many cases this segment obliterates the boundary between the other segments and intertwines various ethnic and social factors into an intricate knot. Even in the works of those linguists and sociologists, who acknowledge the role of the family in ethnic assimilation, that role is stated simply by saying, e.g., that ethnically mixed families must be taken into account in those processes. Occasionally that role is exaggerated, without specifying the nationalities and the types of mixed families, the scale of assimilation and what national communities are affected by the 'family intervention' into the processes, taking place in the region. The study of these issues, understandably, rarely goes behind the confines of linguistic research.

The studies related to the role of the family in the ethnic processes of south-eastern Lithuania in the second half of the 
twentieth century can be divided into two groups, published (1) during the Soviet occupation and (2) after the reestablishment of the Lithuanian state. The former, written in the conditions of strict political censorship, are characterized by rather cautious conclusions in which it is difficult to discern the opinion of the authors on ethnic problems. The studies of the Lithuanian ethnologists Angele Vyšniauskaite $\dot{e}^{4}$ and Antanas Daniliauskas ${ }^{5}$ were the first works, in which the role of the family was treated briefly in the demographic characteristic and internal organization of the family of the population of south-eastern Lithuania. Natural assimilation and its consequences for the demographic changes of the region were also dealt with by a number of Lithuanian linguists, who investigated the dialectal varieties, linguistic contacts, influences and ethnolinguistic processes in the Lithuanian villages of the south-eastern Lithuania as well as those on the other side of the eastern Lithuanian boundary. In this respect the works of Jadvyga Kardelyte் $^{6}$, Aloyzas Vidugiris ${ }^{7}$, Simas Karaliūnas ${ }^{8}$, Janina Lipskienè ${ }^{9}$, Kazimieras Garšva and Oleg Poliakov ${ }^{10}$ and Jakovas Trifonovas ${ }^{11}$ deserve mention. All these authors nearly unanimously adhere to the opinion that ethnically mixed families played a significant role in the assimilation, and that this process, as a rule, was not favourable for the Lithuanians. The factors of ethnic assimilation in south-eastern Lithuania were researched in greater detail by some émigré scholars of Lithuanian descent. The book Rytu Lietuva (Eastern Lithuania), ${ }^{12}$ published in the

${ }^{4}$ A. Vyšniauskaitè. Valstiečių šeima. Dieveniškès. Vilnius, 1968, 177-184.

${ }^{5}$ A. Daniliauskas. Valstiečių šeima. Gaidès ir Rimšés apylinkès. Vilnius, 1969, 191-197.

${ }^{6}$ J. Kardelytè. Gervéčiu tarmé. Vilnius, 1975.

7 A. Vidugiris. Dèl kalbų kontaktavimo Pietryčių Lietuvoje. Kalbų kontaktai Lietuvos TSR. Lietuvių kalbotyros klausimai (hereafter LKK), XXVII, Vilnius, 1983, 46-61.

${ }^{8}$ S. Karaliūnas. Respublikos lingvosocialinès situacijos charakteristika. Kalbu kontaktai Lietuvos TSRS, KLK, XXVIII, Vilnius, 1983, 4-45.

${ }^{9}$ J. Lipskienè. Gervèčių šnektos ištiktukai. Kalbu ryšiai ir sq̨veikos. LKK. XXVIII, Vilnius, 1989, 118-126.

${ }^{10}$ K. Garšva, O. Poliakov. Litovskii govor v okruge Opsy. Kalbų ryšiai ir sąveikos. LKK. XXVIII, Vilnius, 1989, 99-117.

${ }^{11} \mathrm{~J}$. Trifonovas. Jazykovye processy v etnicheskikh smeshannykh semiakh. Kalbų ryšiai ir squveikos. LKK. XXVIII, Vilnius, 1989, 149-152.

${ }^{12}$ Rytu Lietuva. Chicago, Ill., 1980. 
USA in 1980, contains a chapter on the demographic problems of the Vilnius region. The author of the chapter Algirdas Budreckis distinguishes three causes in the Slavonization of this region during the Soviet occupation: deportation of Lithuanians, the population migration, and the reconciliation of the Lithuanians to the influence of Polish and Eastern Slavonic cultures'. ${ }^{13}$

After the re-establishment of Lithuanian statehood, linguists investigating this region continued paying special attention to the role of the family in linguistic assimilation, and in their works they infrequently stated that the existence of ethnically mixed families leads to deeper ethnic changes, to the transformations of ethnic self-consciousness, and finally to the changes in the national composition of the population. Among the recent studies those of Pranas Kniūkšta ${ }^{14}$, Simas Karaliūnas ${ }^{15}$, Laima Grumadienè ${ }^{16}$ and Kazimieras Garšva ${ }^{17}$ should be mentioned.

A monograph ${ }^{18}$ by the linguist Zigmas Zinkevičius should be given particular attention. Without denying the role of the family in his book, the author considers that the reason of the assimilation of ethnic Lithuanians in south-eastern Lithuania in the years of Soviet occupation was the forcible assimilation (education policy, the selection of officials, the persecution of the Lithuanian language, etc.). The author maintains that the effect of forcible assimilation was most easily achieved through schools, 'when even the parents with a good command of Lithuanian stopped speaking with their children in their native tongue in order to make their studies in a Polish or Russian school easier'. ${ }^{19}$

A joint monograph of the Institute of Philosophy and Sociology Vilniečio portretas: sociologiniai metmenys (Portrait of the Vilnensian: Sociological Outline) deals with many ethno-

${ }^{13}$ Ibid., 330-331.

${ }^{14}$ P. Kniūkšta. Vilniaus kraštas ir lietuvių kalba. Vilnius, 1990.

${ }^{15} \mathrm{~S}$. Karaliūnas. Tauta, visuomenè ir lietuvių kalbos vartojimas. Kalbos normalizacijos klausimai. LKK, XXXI, Vilnius, 1992, 26-50.

${ }^{16}$ L. Grumadienè. Kaip kalbama Dieveniškių apylinkèse. Dieveniškès, Vilnius, 1995, 461-467.

${ }^{17}$ K. Garšva. Pietryčių Lietuvos gyventojų tautinès ir kalbinès orientacijos 1989 metais. Lituanica, 3(19), 1994, 28-35.

${ }^{18}$ Z. Zinkevičius. Rytu Lietuva praeityje ir dabar. Vilnius, 1993.

${ }^{19}$ Ibid., 250. 
social issues. However, it does not contain a chapter, relating to the natural national assimilation or ethnodemographic processes. True, the chapter on language and nationality (by Eugenija Krukauskiene) states that the language of the family (of the head of the family) is decisive for the children in the choice of their nationality. ${ }^{20}$ In a collection of articles, issued by the same Institute, Paribio Lietuva (Boundary Lithuania) Juozas Lakis attributes possible changes in the national identity of the population of south-eastern Lithuania to the choice of school, in which tuition is Lithuanian, Polish or Russian. ${ }^{21}$

The investigator of demographic geography Petras Gaučas also wrote about the role of ethnic assimilation in the demographic processes of south-eastern Lithuania. ${ }^{22}$ The author considers the closure of Lithuanian schools after the Second World War was the main Slavonization factor of the Lithuanian population in the region. In his other work, Gaučas shows that Lithuanian was the native tongue of up to 50 per cent of the pupils, when their schools were turned into Polish ones in 195153, and those who had attended these schools forgot Lithuanian by the 1990s. ${ }^{23}$ Thus, the family could not at least neutralize the aftermath of forced assimilation.

This paper aims at determining the effect of natural assimilation (mostly in the framework of the family) on the ethnodemographic development of the south-eastern region of Lithuania in the second half of the twentieth century. The research is based on the official state statistics and on the author's interviews with the inhabitants of the districts of Šalčininkai, Švenčionys, Trakai and Vilnius in the period between 1993 and 1995.

The existence and spontaneous manifestation of natural ethnic assimilation in a polyethnic environment must be acknowledged, and at the same time it must be stated that due to this factor alone the national composition of the population does not change so rapidly as it does as a result of forced assimilation

${ }^{20}$ E. Krukauskienė. Kalba ir tautybè. Vilniečio portretas: sociologiniai matmenys, Vilnius, 1995, 71.

${ }^{21}$ J. Lakis. Mokyklų kontingentų pokyčiai etnokultūrinių procesų kontekste. Paribio Lietuva. Vilnius, 1996, 218-228.

22 P. Gaučas. Dieveniškių apylinkių ir jų kaimyninių sričių gyventojų etnolingvistinès sudèties raida XIX ir XX a. istorinių (kartografinių, statistinių, literatūrinių) šaltinių šviesoje. Dieveniškès. Vilnius, 1995, 176-207.

${ }^{23}$ P. Gaučas. Bendrojo lavinimo mokyklų tinklo raida Dieveniškių apylinkèje 1944-92 m. Dieveniškès. Vilnius, 1995, 116-138. 
and actions of ethnic cleansing of a particular territory. These phenomena could be observed in a number of countries during the Second World War, when totalitarian states divided Europe redrawing the national boundaries by military means and endeavouring by various violent measures to change the national composition of ethnically mixed populations in the border regions. The south-eastern region of Lithuania was one of such areas. During the Second World War alone it changed hands five times. Simultaneously several states laid claims to this territory due to its ethnic heterogeneity, its complex history and geographical position. The Soviet Union and Poland among them even took some steps to cleanse this territory ethnically in their own favour. Soviet actions were the 1941 and post-war deportations of the Lithuanian population and the resettlement of the people from other republics of the Soviet Union and later the constant encouragement of the immigration of Russians, Belorussians and Poles to this region. The activity of the Armia Krajowa (henceforth AK) during the war years should also be mentioned in this context. This military organization, directed by the Polish exile government in London, was responsible to a considerable extent for the formation of the present-day national composition in south-eastern Lithuania. The activities of the AK in Lithuania differed significantly from those in Poland. Here they were directed against Lithuanians rather than Germans or Bolsheviks. In Lithuania the members of the AK killed a number of civilian Lithuanians, people of peaceful professions: farmers, foresters, teachers and clergymen. On 13 June 1941, when Vilnius was a no man's land for a short time (with the Germans retreating and the Soviets invading), the AK murdered indiscriminately people of Lithuanian descent without regard to sex or age. ${ }^{24}$ True, during the Second World War such actions did not always end in massacres, sometimes Lithuanians were required simply to leave the place of residence. All that shows that these operations of ethnic cleansing of south-eastern Lithuania were conducted deliberately in anticipation of a possible redrawing of the borders of post-war states and a possible plebiscite on the political status of this region. The exact number of the civilian victims of the AK actions is not known, however, the ethno-demographic consequences of that terror are quite evident. The data of both the population register of 1909 (compiled by the local

${ }^{24}$ Armija Krajova Lietuvoje. Vilnius, 1995, 90-91, 113-114. 
administration of the Vilnius Gubernia), ${ }^{25}$ the Polish census of $1931^{26}$ and the population register of the Generalbezirk Litauens (Lithuanian General District), carried out in $1942,{ }^{27}$ testify to the presence of a greater or smaller percentage of the Lithuanian population in the area along the present-day border with Belorussia. Meanwhile after the Second World War, Lithuanians practically disappeared in such places as Turgeliai, Akmenyne, etc., and in Dieveniškès and its environs their numbers suddenly decreased. It is noteworthy that these localities were the main places, where the AK units were stationed. Due to the terror of the AK, Lithuanians often had to flee from those places or to adapt themselves by renouncing their nationality.

Later, in the 1950s, the Soviet authorities closed 367 schools in south-eastern Lithuania. ${ }^{28}$ Thus, many localities were deprived even of Lithuanian primary schools, and Lithuanian families, dispersed by the war, could not return to their native places because of the absence of schools with the instruction in the native tongue. Those Lithuanians that remained in such localities were Slavonized in the process of spontaneous ethnic assimilation.

It is understandable that despite various official measures of the authorities, directed towards national amalgamation and stimulation of migration, the change of the ethnic structure of a particular territory would be much slower but for the behaviour of the inhabitants themselves, i.e., their participation in natural ethnic assimilation. Certain cases in south-eastern Lithuania under the Polish occupation between 1920 and 1939 can be typical examples of serious obstacles in the way of forced assimilation. These are the circumstances when ethnically homogeneous families predominate in a particular area. In the two decades of the occupation the influence of Polonization was insignificant in those rural districts, where the Lithuanians were in the majority and their families were not mixed despite discriminatory measures of forced assimilation - the closure of Lithuanian schools and cultural organizations, the ban on the employment of Lithuanians in state institutions or their purchase of land, etc. On the other hand, the localities, in the occupation period

${ }^{25}$ P. Gaučas. Lietuvių-gudų kalbų paribio etnolingvistinė situacija 17951914 m. Lietuvos Rytai. Vilnius, 1993, 97-98.

${ }^{26}$ Drugi powszechny spis ludności z. dn. 9 XII. 1931 R. Wojewódstwo Wileńskie (Bez miasta Wilna). Warszawa, 1936, 10-11.

${ }^{27}$ LCVA, f. R-743, ap. 5, b. 45, 1. 4; ap. 2, b. 10265, 1. 29.

${ }^{28}$ Z. Zinkevičius. Rytų Lietuva praeityje ir dabar: Vilnius, 1993, 243. 
inhabited by approximately equal numbers of Lithuanian and Slavonic nationalities, today are almost purely Slavonic, excepting the Lithuanians, who moved here from other districts of Lithuania after the war. Certainly, this is not the only resistance factor, no matter how important it may be. The ethnic diversity of any territory always leads to mixed marriages despite the customary restrictions, existing as a rule among nations. South-eastern Lithuania is inhabited by the representatives of a number of nations. A high degree of ethnic heterogeneity (four nations - Lithuanians, Poles, Russians and Belorussians) created favourable conditions for a high percentage of ethnically mixed marriages. In 1991 in the four southeastern Lithuanian districts monoethnic marriages made up 57 per cent and mixed marriages 43 per cent. In the district of Šalčininkai monoethnic marriages constituted 70 per cent and mixed marriages 30 per cent, in the district of Švenčionys 54 per cent and 46 per cent respectively, in the district of Trakai 56 and 44 per cent and in the district of Vilnius 53 and 47 per cent. ${ }^{29}$

Ethnic assimilation is a problem of the survival of diasporas, ethnic communities and even of numerous nations. The evaluation of the role of mixed families in ethnic assimilation is a complicated issue, implying the dynamics of the birth-rate and the population migration. Thus, higher birth-rates of some nations can compensate even a huge loss, caused by ethnic assimilation. And conversely, a low birth-rate and assimilative losses can lead to a depressing situation in the life of any nation. In the former case, despite great losses in the ethnically mixed families the number of children of a particular nationality can always be higher than the number of parents of that nationality in society. In the latter case, in spite of small losses in mixed families and even of some increase due to assimilation, the number of the children of the national assimilator can be permanently smaller in comparison with the number of the parents of that nationality. Due to a low birth-rate the ethnic community gradually decreases. In both cases migration can notably affect the size of the ethnic population, either compensating its decrease and even increasing it or producing adverse results. Therefore the treatment of assimilative results, attained by ethnically mixed families, and their effects on the

${ }^{29}$ Lietuvos centrinis metrikų archyvas. Miestų ir rajonų fondas, b. 375, santuokos aktụ ịrašai (s.a.į) 1-202; b. 376, s.a.i. 203-294; b. 432, s.a.į. 1-200; b. 433, s.a.i. 201-267; b. 460, s.a.i. 1-291; b. 461, s.a.i. 292-586; b. 589, s.a.ị. 1-260, b. 590 , s.a.i. $261-530$, b. 591 , s.a.i. $531-708$. 
demographic changes should be twofold: (1) who in the process of assimilation ('the division of children' in mixed families) is the winner and who is the loser and what the gains or the losses are, and (2) what the number of the descendants of that particular nation is, including both mixed and monoethnic families, in other words, what the total balance of the progeny is - does it increase, decrease or remain without change in the society of that nation?

Examining natural ethnic assimilation in south-eastern Lithuania from the first aspect (see Table 1) one can see the regularities, common for the whole of Lithuania: Lithuanians are the main assimilators of other nations. In the case of the assimilation Russian versus Lithuanian, the Russians yield to the Lithuanians. In south-eastern Lithuania, however, the Poles formally take precedence over the Russians in contrast to the whole of Lithuania, since in general the Russians are the assimilators of the Poles here. The Poles (together with the Lithuanians and the Russians) are the assimilators of the small ethnic minorities. There is one more feature, peculiar to the whole of Lithuania - adherence to the tradition to identify the nationality of the children with that of the father rather than of the mother. True, this is the situation when both parents belong to large ethnic communities. When the father is a representative of a small community, this tradition is usually not observed. One more peculiarity of south-eastern Lithuania is a rather frequent request of the parents to establish the nationality of their children other than their own. There are several reasons for that. For some people a certain nationality seems more prestigious (usually it is Lithuanian or Russian, less frequently Polish). In the past during the Polish and later Soviet occupation - the nationality of some people was changed by administrative means disregarding their national self-consciousness. After the demise of the Soviet Union such people applied to the authorities for the passports with the indication of the nationality to which their parents belonged.

The comparison of the nationality of the elder and younger children in a family reveals the changes in the prestige of a particular nationality and in the trends of the assimilation process.

Table 1 Distribution of Children According to Nationalities in the Families Investigated in 1995*

\begin{tabular}{|c|l|c|c|c|c|}
\hline \multicolumn{2}{|c|}{ Nationality } & \multicolumn{2}{c|}{ The first children } & \multicolumn{2}{c|}{$\begin{array}{c}\text { Younger (the last) } \\
\text { children** }\end{array}$} \\
\hline of parents & of children & number & $\%$ & number & $\%$ \\
\hline Lithuanian & Lithuanian & 204 & 98.5 & 151 & 98.7 \\
& Polish & 3 & 1.5 & 2 & 1.3 \\
\hline
\end{tabular}


Cont.

\begin{tabular}{|c|c|c|c|c|c|}
\hline \multicolumn{2}{|c|}{ Nationality } & \multicolumn{2}{|c|}{ The first children } & \multicolumn{2}{|c|}{$\begin{array}{l}\text { Younger (the last) } \\
\text { children** }\end{array}$} \\
\hline of parents & of children & number & $\%$ & number & $\%$ \\
\hline \multirow[t]{4}{*}{ Polish } & Polish & 153 & 91.6 & 119 & 93.7 \\
\hline & Lithuanian & 11 & 6.6 & 6 & 4.7 \\
\hline & Russian & 1 & 0.6 & 1 & 0.8 \\
\hline & Belorussian & 2 & 1.2 & 1 & 0.8 \\
\hline \multirow[t]{2}{*}{ Russian } & Russian & 45 & 95.7 & 37 & 94.9 \\
\hline & Lithuanian & 2 & 4.3 & 2 & 5.1 \\
\hline \multirow{4}{*}{$\begin{array}{l}\text { Other } \\
\text { of the same } \\
\text { nationality }\end{array}$} & nationality & & & & \\
\hline & $\begin{array}{l}\text { of the parents } \\
\text { Lithuanian }\end{array}$ & $\begin{array}{c}32 \\
5\end{array}$ & $\begin{array}{l}80.0 \\
12.5\end{array}$ & $\begin{array}{l}25 \\
3\end{array}$ & $\begin{array}{l}83.4 \\
10.0\end{array}$ \\
\hline & Russian & 2 & 5.0 & 1 & 3.3 \\
\hline & Polish & 1 & 2.5 & 1 & 3.3 \\
\hline Lithuanian- & Lithuanian & 108 & 87.8 & 47 & 85.5 \\
\hline \multirow{2}{*}{ Polish } & Polish & 15 & 12.2 & 7 & 12.7. \\
\hline & Russian & - & - & 1 & 1.8 \\
\hline Lithuanian- & Lithuanian & 41 & 83.7 & 19 & 86.3 \\
\hline Russian & Russian & 8 & 16.3 & 3 & 13.7 \\
\hline Polish- & Lithuanian & - & - & 1 & 3.3 \\
\hline \multirow[t]{2}{*}{ Russian } & Polish & 35 & 58.3 & 17 & 56.7 \\
\hline & Russian & 25 & 41.7 & 12 & 40.0 \\
\hline Polish- & Polish & 41 & 91.1 & 21 & 65.6 \\
\hline \multirow[t]{3}{*}{ Belorussian } & Belorussian & 4 & 8.9 & 5 & 15.6 \\
\hline & Russian & - & - & 4 & 12.5 \\
\hline & Lithuanian & - & - & 2 & 6.3 \\
\hline
\end{tabular}

Table 1 is based on the materials of Lietuvos istorijos instituto Etnologijos skyriaus Rankraštynas (henceforth ES), b. 1994/1, 1. 1-199; b. 1994/2, 1. 200380; b. 1994/3, 1. 381-562; b. 1994/4, 1. 563-743.

*The data are based on the parents' answers about the nationality of their children, which is indicated in their passports and about the desired nationality of young children.

**For the purposes of statistics the younger child was taken into account in a family of two children and in case of families with more than two children the youngest child.

The data of Table 1 show that in recent years all nations in south-eastern Lithuania began paying greater attention to the nationality - in all monoethnic families younger children less frequently than the elder ones were assigned by their parents not totheir own but to some other nationality. Only the representatives of some nations still wished to see their children as members of other than their own nationalities. In general, it can be surmised that the increased attention to one's own nationality among all nations is connected with the rise of national self-consciousness and the aspirations to recover the lost 
nationality after the disintegration of the Soviet regime. The growth of national ambitions is also observed in the data related to mixed families with four - five children: the elder three - four children belonged to one (usually more numerous) nationality, and the youngest child was of another nationality (mostly that of one of the parents, belonging to a small nationality). Nothing of that kind could be observed in Soviet times, this new phenomenon appeared only after 1988-1990. Thus, the Lithuanian national rebirth contributed to the rise of the self-consciousness of ethnic minorities in the country.

As has already been observed, assimilation results can be substantially modified by the birth-rate. The statistics show that the differences in the birth-rate of various nations in Lithuania are not great. According to the 1989 census the birth-rate was the following for 1,000 people of different nationalities: 15.4 children of Lithuanian women, 15.6 Polish, 12.3 Russian and 19.3 Belorussian respectively. ${ }^{30}$ Attention perhaps could be drawn only to the fact that the women of the main assimilators - Lithuanians and Russians - produce less children than the women of the assimilated nations, in particular the Belorussians. Thus the Lithuanians and the Russians in a way give the ethnic Polish and Belorussian families a chance to compensate for the losses, sustained in mixed families, because in 'the division of children' (taking Lithuania as a whole) the Polish and Belorussian part of children is much smaller than that of the Lithuanians and the Russians.

The ethnic differences of south-eastern Lithuania are shown in Table 2, which indicates that the main differences here are the same as in the rest of Lithuania. None of the major nationalities are either distinct outsiders or leaders - Lithuanian and Russian women produce only slightly less children than the Polish and Belorussian women. Thus in the ethnically heterogeneous region of south-eastern Lithuania the ratio between the Polish and Belorussian birth-rates and the Russian and Lithuanian ones should change in favour of the former. However, Table 3 shows that this is not the case. A greater birthrate fails to increase not only the Belorussian community and other smaller ethnic minorities, but also the Polish population. The cause of this situation is natural ethnic assimilation. The total increase is peculiar only to the Lithuanians, because in the process of natural ethnic assimilation they 'overcome' all national minorities of the country (among them the Russians and the Poles), and with regard to the birth-rate they slightly lag behind

${ }^{30}$ Lietuvos gyventojai. Statistikos rinkinys. Vilnius, 1990, 23. 
the Poles and the Belorussians and are ahead of the Russians. The Russians are very near to the positive result, since they also assimilate minor ethnic minorities - Belorussians, Ukrainians, Jews, Tartars, etc. - doing even more intensively than the Poles. Among the smallest ethnic minorities only the Karaites (Karaims) and partly the Tartars are near the positive balance due to their successful resistance to natural ethnic assimilation. Higher Belorussian and Polish birth-rates in south-eastern Lithuania do not increase these populations, because they do not outweigh the significant losses in the natural ethnic assimilation. Table 3 also indicates that the situation in the districts of south-eastern Lithuania is far from uniform. The Poles have a positive balance in the districts of Šalčininkai and Vilnius, in which the Lithuanian increase is lower compared to all the four districts taken together. The Russians have a positive balance in the district of Švenčionys, in which the Lithuanian increase is also most considerable, and the Polish decrease is most marked. Among other things, Table 3 also shows that the depopulation in the district of Švenčionys (in the only one of those researched) is not at all a recent phenomenon. The district of Trakai has also been balancing on the verge of depopulation for quite a long time. Depopulation was observed in a number of districts in Lithuania (not only in the south-east) already in Soviet times. Therefore Lithuanian demographers are considering whether depopulation was encoded in the demographic development of the community, or whether it is more connected with the socio-economic changes of the recent years. ${ }^{31}$

Table 2

Birth-rate data according to nationalities in south-eastern Lithuania

\begin{tabular}{|c|c|c|c|c|}
\hline \multicolumn{3}{|c|}{ Mothers' } & \multirow[t]{2}{*}{ Number of children } & \multirow{2}{*}{$\begin{array}{c}\text { Average } \\
(\%)\end{array}$} \\
\hline nation & & number & & \\
\hline Lithuanian & & 184 & 315 & 1.71 \\
\hline Polish & & 222 & 418 & 1.88 \\
\hline Russian & & 66 & 109 & 1.65 \\
\hline Belorussian & & 55 & 96 & 1.74 \\
\hline & Total & 527 & 938 & 1.77 \\
\hline
\end{tabular}

The Table is based on the fieldwork results, obtained by the author: ES, b. 1994/1, 1. 1-199; b. 1994/2, 1. 200-380; b. 1994/3, 1. 381-562; b. $1994 / 4,1.563-743$.

${ }^{31}$ In greater detail see V. Stankūnienė. Pastarųjų metų gimstamumo pokyčiai: adaptacija ir naujos reprodukcinès elgsenos modelio apraiškos. Šeima ir gimstamumas Lietuvoje. Vilnius, 1997, 84-107. 
Table 3

Reproduction balance according to nationality in south-eastern Lithuania (including birth-rate and assimilation)

\begin{tabular}{|c|c|c|c|c|}
\hline \multirow[t]{2}{*}{ Nationality } & \multicolumn{2}{|c|}{$\begin{array}{l}\text { Parents of monoethnic and } \\
\text { mixed families }\end{array}$} & \multicolumn{2}{|c|}{$\begin{array}{l}\text { Children of monoethnic and } \\
\text { mixed families }\end{array}$} \\
\hline & Number & $\%$ & Number & $\%$ \\
\hline \multicolumn{5}{|c|}{ In the four investigated districts } \\
\hline $\begin{array}{l}\text { Lithuanian } \\
\text { Polish } \\
\text { Russian } \\
\text { Belorussian } \\
\text { Other }\end{array}$ & $\begin{array}{r}536 \\
476 \\
173 \\
96 \\
58 \\
1339\end{array}$ & $\begin{array}{c}40.0 \\
35.5 \\
12.9 \\
7.2 \\
4.3 \\
100.0\end{array}$ & $\begin{array}{c}642 \\
445 \\
163 \\
51 \\
47 \\
1348\end{array}$ & $\begin{array}{c}47.6 \\
33.0 \\
12.1 \\
3.8 \\
3.5 \\
100.0\end{array}$ \\
\hline \multicolumn{5}{|c|}{ In Śvenčionys district } \\
\hline $\begin{array}{l}\text { Lithuanian } \\
\text { Polish } \\
\text { Russian } \\
\text { Belorussian } \\
\text { Other }\end{array}$ & $\begin{array}{c}173 \\
97 \\
39 \\
28 \\
- \\
337\end{array}$ & $\begin{array}{c}51.3 \\
28.8 \\
11.6 \\
8.3 \\
- \\
100.0\end{array}$ & $\begin{array}{c}191 \\
57 \\
42 \\
13 \\
- \\
303\end{array}$ & $\begin{array}{c}63.0 \\
18.8 \\
4.3 \\
4.3 \\
- \\
100.0\end{array}$ \\
\hline \multicolumn{5}{|c|}{ In Trakai district } \\
\hline $\begin{array}{l}\text { Lithuanian } \\
\text { Polish } \\
\text { Russian } \\
\text { Belorussian } \\
\text { Tartar } \\
\text { Karaite } \\
\text { Other }\end{array}$ & $\begin{array}{c}158 \\
67 \\
44 \\
11 \\
8 \\
22 \\
7 \\
321\end{array}$ & $\begin{array}{c}49.2 \\
20.9 \\
13.7 \\
3.4 \\
2.5 \\
6.9 \\
3.4 \\
100.0\end{array}$ & $\begin{array}{c}194 \\
53 \\
42 \\
5 \\
9 \\
24 \\
2 \\
329\end{array}$ & $\begin{array}{c}59.0 \\
16.1 \\
12.8 \\
1.5 \\
2.5 \\
7.3 \\
0.6 \\
100.0\end{array}$ \\
\hline \multicolumn{5}{|c|}{ In Vilnius district } \\
\hline $\begin{array}{l}\text { Lithuanian } \\
\text { Polish } \\
\text { Russian } \\
\text { Belorussian } \\
\text { Other }\end{array}$ & $\begin{array}{c}147 \\
176 \\
48 \\
21 \\
9 \\
401\end{array}$ & $\begin{array}{c}36.6 \\
43.9 \\
12.0 \\
5.2 \\
2.2 \\
100.0\end{array}$ & $\begin{array}{c}177 \\
186 \\
38 \\
10 \\
5 \\
416\end{array}$ & $\begin{array}{c}42.5 \\
44.7 \\
9.1 \\
2.4 \\
1.2 \\
100.0\end{array}$ \\
\hline \multicolumn{5}{|c|}{ In Šalčininkai district } \\
\hline $\begin{array}{l}\text { Lithuanian } \\
\text { Polish } \\
\text { Russian } \\
\text { Belorussian } \\
\text { Other }\end{array}$ & $\begin{array}{c}58 \\
136 \\
42 \\
36 \\
8 \\
280\end{array}$ & $\begin{array}{c}20.7 \\
48.6 \\
15.0 \\
19.9 \\
2.9 \\
100.0 \\
\end{array}$ & $\begin{array}{c}80 \\
149 \\
41 \\
23 \\
7 \\
300\end{array}$ & $\begin{array}{c}26.7 \\
49.7 \\
13.7 \\
7.7 \\
2.3 \\
100.0\end{array}$ \\
\hline
\end{tabular}

The Table is compiled on the basis of the fieldwork results, obtained by the author: ES, b. 1994/1, 1. 1-199; b. 1994/2, 1. 200-380; b. 1994/3, l. $381-562$; b. $1994 / 4$, 1. 563-743. 
It must be noted that formal natural assimilation ( a more frequent adoption of the Lithuanian nationality rather than of any other by the children of mixed families under discussion here) does not lead to an analogous linguistic and cultural assimilation in south-eastern Lithuania. In this respect the Polish community of the region is not Lithuanianized. This kind of situation is acknowledged by other investigators as well. ${ }^{32}$

Intensive migration from other countries or ethnic territories, however, can radically change the national composition of the population despite the birth-rate and the assimilation balance of the local population. The further Slavonization of the south-eastern districts of Lithuania was most effectively implemented by the immigration of Slavonic nationals from Belorussia, Russia and Ukraine, and by the deliberate Russification policy of languages and schools. After the reestablishment of Lithuania's independence in 1990, the migration factor was not fully eliminated from the ethnic processes. However, its effectiveness was seriously weakened. Immigration into Lithuania became less intensive, and emigration from Lithuania increased after its international recognition at the end of 1991. According to official statistics, in the period between the Second World War and 1959 the number of Lithuanians greatly reduced in the entire south-eastern region. In the following three decades the percentage of the Lithuanian population rose from 7 to 21 points. At the same time, there was an increase in the Belorussian immigration and a decrease of the Polish immigration. It must also be recognized that the Polish community decreased in the district of Vilnius as a result of the internal migration, i.e., young rural people moved to towns and in particular to Vilnius in search of better jobs and wages as well as leisure facilities. In Soviet times (until the 1980s) this sort of migration was commonplace in the Lithuanian country life. Meanwhile the Lithuanian population increased very insignificantly (from 6.4 per cent to 9.4 per cent) and the number of the Poles decreased slightly (from 83.9 per cent to 79.6 per cent) in the district of Salčininkai between 1959 and 1989. Between 1979 and 1989 the Lithuanian percentage grew more rapidly - from 7 to 9 , and the number of Poles decreased by 2.000 (by ca. 2 per cent). ${ }^{33}$ Many Poles moved to Vilnius and other

${ }^{32}$ T. Leončikas. Lietuvos lenkų tapatybès formavimasis (po Lietuvos nepriklausomybės atkūrimo). Lietuvos socialinès panoramos kontūrai. Vilnius, 1997, 84-107.

${ }^{33}$ Lietuvos Respublikos pagrindiniu tautybiu gyventojai. Vilnius, 1991, 35. 
towns from the districts of Šalčininkai and Vilnius. However, due to the enormous previous disproportion between the Poles and Lithuanians, the latter changes could not appreciably affect the ethnodemographic structure of the region. After the restoration of the Lithuanian state, the change of the migratory direction of the Poles, Belorussians and Russians to a great extent modified the proportions between the nationalities in the country. ${ }^{34}$ However, it is interesting that while the percentage of Russians, Belorussians and Ukrainians decreased, it was only the number of Poles which increased from 7 per cent to 7.1 per cent. ${ }^{35}$ That meant an increase of over 3,700 persons. In 1990 the number of Poles, coming to Lithuania was greater than the number of those leaving it. ${ }^{36}$ This situation was probably conditioned by greater chances for the Poles to realize their national self-actualization in Lithuania than in Belorussia, Ukraine, Russia and even in Latvia. Nowhere else, except Lithuania, could the Poles study in their native tongue in the higher schools, in Polish special vocational schools, secondary and elementary schools and use Polish in public life and in working places, etc.

Thus, it can be maintained that during the last decades Polish, Russian and Belorussian communities grew mostly at the expense of migration. In the Soviet period immigration radically changed the ethnic composition of one more eastern district Ignalina. When in the 1980 s the atomic power station at Ignalina and the settlement of Visaginas were constructed, about 30,000 immigrants, mostly Russians, settled there, reducing the Lithuanian percentage of 64.3 in 1979 to 39.2 in $1989 .{ }^{37}$ Immigration was also intensive in the south-east, in particular in the districts of Šalčininkai and Vilnius. The 1989 fieldwork experience of the Lithuanian Institute of History and the Institute of Philosophy, Sociology and Law showed that 22.3 per cent of the inhabitants of the Salčininkai district had been born in Belorussia, Russia, Ukraine and of the republics of the USSR, and 16 per cent in Belorussia alone. ${ }^{38}$ In his research in 1993-95 the author of this study established that 26 per cent of the Poles,

${ }^{34}$ Lietuvos statistikos departamento darbai. 1992, 3. Vilnius, 1993, 46-47.

${ }^{35}$ Lietuvos statistikos departamento darbai. 1993. Vilnius, 1993, 17.

${ }^{36}$ Ibid., 16.

${ }^{37}$ Lietuvos Respublikos pagrindiniu tautybiu gyventojai. Vilnius, 1991, 31.

${ }^{38}$ A. Eigirdas. Migracija ir visuomeninès politinès nuostatos. Lietuvos Rytai. Vilnius, 1993, 329. 
61 per cent of the Russians and 86 per cent of the Belorussians, living at that time in the four districts of south-eastern Lithuania, had been born outside the boundaries of those districts. Approximately half of them had been born in other districts and towns of Lithuania, and the other half had arrived from other Soviet republics. A more detailed analysis of the effect of migration on ethnodemographic processes is beyond the scope of this paper.

\section{Conclusions}

Ethnic processes, taking place on the fringes of a country in the nationally mixed regions, are continually influenced by historic, legal and political factors. Their intermixture and the specific features of the south-eastern districts of Lithuania conditioned and are still conditioning many ethnodemographic processes in this area along the Lithuanian border with Belorussia.

The formation of the ethnic composition of this region was affected by the terror, exercised by the Polish military organization Armia Krajowa during the Second World War and afterwards by the Soviet deportations of the population and the transformation of nearly all Lithuanian schools into Russian or Polish ones. Still later the immigration of the people of Slavonic descent from other Soviet republics, stimulated by the authorities, also added its share in the formation of the demographic situation.

Ethnic heterogeneity of the region in the second half of the twentieth century created favourable conditions for mixed marriages. Thus, natural ethnic assimilation led to the changes in the ethnodemographic structure of the region as well.

Judging by formal indicators of natural ethnic assimilation (the division of children in mixed families), Lithuanians could be looked upon as having acquired a certain advantage over other nationalities in the last decades of the Soviet rule. Nevertheless, despite the fact that Poles, Russians, Belorussians and Ukrainians were assimilated by the Lithuanians, their communities constantly grew in south-eastern Lithuania due to population migration, and partly due to a slightly higher birth-rate in some of the national minorities - in the Polish and Belorussian families the number of children is marginally bigger than in Lithuanian families.

The ethnodemographic changes of the second half of the twentieth century were conditioned by population migrations 
rather than by the natural movement of inhabitants and ethnic assimilation. This situation was created to a great degree by the absence of a distinct leader, capable of assimilating other ethnic communities culturally and linguistically in this south-eastern region. Even after the re-establishment of the Lithuanian state, the Russian language, and not Lithuanian or Polish, is mostly used in public life and in everyday communication between the speakers different nationalities in this region. The use of Russian is also widespread in ethnically mixed families. Due to this situation and to the fact that Lithuanians are in the minority in this region, they are incapable of assimilating other nationalities here. 